\title{
PARTISIPASI POLITIK MASYARAKAT DALAM PEMILIHAN UMUM LEGISLATIF DI KOTA DENPASAR
}

\author{
Ni Ketut Arniti \\ Universitas Pendidikan Nasional \\ ketutarniti@undiknas.ac.id
}

Received: 29 June 2020 | Reviewed: 30 June 2020 | Accepted: 17 August 2020

\begin{abstract}
ABSTRAK
Penelitian ini fokus pada partisipasi politik masyarakat dalam pemilihan umum legislatif di Kota Denpasar dalam tahun 2014. Partisipasi penting untuk diteliti mengingat keberhasilan dari sebuah pemilu dapat dilihat dari tingkat partisipasi masyarakat. Dalam penelitian ini, peneliti menggunakan teori partisipasi politik dan teori pilihan rasional. Rumusan masalah yang dibahas dalam penelitian ini, Bagaimana Partisipasi Politik Masyarakat dalam pemilihan umum Legislatif di Kota Denpasar Periode 2014-2019? Adapun hasil dari penelitian ini adalah pertama, peta partisipasi pemilih dalam pileg dan pilpres di Kota Denpasar mengalami kenaikan dan penurunan. Kedua, upaya sosialisasi partisipasi politik yang merupakan bagian paling penting dalam sebuah pemilihan umum. Friedmen dan Hechter melihat adanya pengaruh lembaga sosial dalam partisipasi politik. Dalam temuan peneliti terdapat lembaga sosial yang turut berpengaruh dalam menaik-turunkan partisipasi politik masyarakat, yakni: Kepala Desa, Calon legislatif, PPS, dan tokoh agama. Ketiga, kedekatan emosional calon pileg dan pilpres turut mempengaruhi partisipasi dan persepsi politik masyarakat. Keempat, rasionalitas masyarakat memberikan pengaruh yang sangat besar dalam menentukan partisipasi politik. Pertimbangan ekonomi dan politik uang menjadi salah satu motivasi dalam partisipasi politik. Namun, kedekatan calon dengan pemilih menjadi kunci signifikan dalam pengaruhnya terhadap partisipasi politik masyarakat
\end{abstract}

Kata Kunci: Pileg, Pilpres, Partisipasi Politik, dan Pilihan Rasional

Korespondensi:

Universitas Pendidikan Nasional

Jl. Bedugul No.39, Sidakarya, Kecamatan

Denpasar Selatan, Kota Denpasar, Bali

E-mail: ketutarniti@undiknas.ac.id 


\begin{abstract}
This study focuses on the political participation of the public in the legislative elections in Denpasar City in 2014. Participation is important to study considering that the success of an election can be seen from the level of community participation. In this study, researchers used political participation theory and rational choice theory. The formulation of the problems discussed in this study, How is the Political Participation of the Community in the Legislative General Election in Denpasar City for the 2014-2019 Period? The results of this study are first, the map of voter participation in the legislative and presidential elections in Denpasar City has increased and decreased. Second, efforts to socialize political participation which are the most important part in a general election. Friedmen and Hechter saw the influence of social institutions on political participation. In the findings of the researchers, there are social institutions that have an influence in increasing and decreasing community political participation, namely: Village Heads, legislative candidates, PPS, and religious leaders. Third, the emotional closeness of the legislative and presidential candidates has also influenced the political participation and perceptions of the people. Fourth, the rationality of society has a huge influence in determining political participation. Economic considerations and money politics are one of the motivations for political participation. However, the closeness of candidates to voters is a significant key in influencing people's political participation
\end{abstract}

Keywords: Pileg, Presidential Election, Political Participation, and Rational Choice

\title{
PENDAHULUAN
}

Partisipasi politik menyoal hubungan antara kesadaran politik dan kepercayaan kepada pemerintahan. Sehingga, partisipasi politik erat kaitannya dengan demokrasi dan legitimasi. Partisipasi politik, demokrasi, dan legitimasi memiliki kerangka hubungan yang sangat erat. Partisipasi politik dalam hubungannya dengan demokrasi berpengaruh pada legitimasi masyarakat terhadap jalannya suatu pemerintahan. Dalam suatu pemilu misalnya partisipasi politik berpengaruh terhadap legitimasi masyarakat kepada pasangan calon yang terpilih. Setiap masyarakat memiliki preferensi dan kepentingan masing-masing untuk menentukan pilihan mereka dalam pemilu. Tidak hanya itu, partisipasi politik masyarakat dalam pemilu dapat dipandang sebagai kontrol masyarakat terhadap suatu pemerintahan. Kontrol yang diberikan beragam tergantung dengan tingkat partisipasi politik masing-masing. Selain sebagai inti dari demokrasi, partisipasi politik juga berkaitan erat dengan pemenuhan hak-hak politik warga negara. 
Alat ukur untuk mengetahui partisipasi, demokratisasi, dan legitimasi warga negara Indonesia dapat dilihat salah satunya melalui perilaku politiknya. Perilaku politik itu dapat dilihat dari berbagai jenis yaitu melalui aktivitas dan antusiasme masyarakat mendatangi tempat pencoblosan dalam pemilihan umum. Bentuk perilaku politik ini menjadi alat analisis untuk melihat partisipasi politik masyarakat itu sendiri. Termasuk di dalamnya pada pemilihan legislatif tahun 2014 yang lalu. Data resmi KPU Pusat meliris bahwasanya partisipasi pemilih pemilu legislative tahun 2014 bergerak fluktuatif.

Dalam setiap penyelenggaraan pemilihan umum, tidak terlepas dari masalah yang tentu saja akan menjadi kendala. Hal tersebut juga terlihat pada pemilihan umum Legislatif 2014 di Kota Denpasar kendala yang sering muncul misalnya proses pemilihan yang rumit dan selain itu kurangnya sosialisasi KPUD untuk menerangkan tata cara pemberian suara. Yang dulunya mencentang atau menandai kemudian diganti dengan cara mencoblos, pada pemilu 2014 yang semuanya ini diatur dalam Undang-undang Nomor 8 tahun 2014 tentang Pemilihan Umum Anggota DPR, DPD, DPRD undang nomor 8 tahun 2011 tentang Pemilihan umum Anggota DPR, DPD, DPRD yang tentu saja menjadi landasan hukum dari penyelenggara pemilu Anggota DPR, DPD, dan DPRD dan juga bertujuan menghasilkan pemilu yang berkualitas agar dapat menjamin adanya kompetisi yang sehat, partisipatif, mempunyai derajat keterwakilan yang lebih tinggi dan memiliki mekanisme pertanggungjawaban yang jelas. Hal ini hanya bisa dicapai apabila pemilihan umum itu diselenggarakan berdasarkan asas langsung, umum, bebas, rahasia, jujur dan adil.

Dalam pelaksanaan Pemilu Legislatif pada tahun 2014 ini diharapkan masyarakat dapat memberikan partisipasi politik secara positif. Partisipasi politik melalui kegiatan pemilihan umum Legislatif yang didasarkan pada demokrasi karena keberhasilan pembangunan tidak hanya semata-mata tergantung pada usaha pemerintah saja tetapi harus adanya dukungan partisipasiseluruh masyarakat terutama dalam memberikan suara dalam pemilihan umum Legislatif di Kota Denpasar.

Penelitian terdahulu yang dilakukan oleh Bismar Arianto (2011) yang berjudul Analisis Penyebab Masyarakat Tidak Memilih Dalam Pemilu menemukan bahwa penyebab utama masyarakat tidak ikut memilih atau tidak menggunakan hak pilihnya dikategorikan dalam dua 
faktor yaitu faktor internal dan faktor eksternal. Selanjutnya yang digolongkan faktor internal yaitu faktor teknis yang merupakan kendala yang bersifat teknis yang dialami oleh seorang pemilih seperti sakit, pemilih sedang ada kegiatan lain dan hal lain yang bersifat pribadi. Hal lain yang termasuk faktor teknis adalah faktor pekerjaan. Sedangkan faktor eksternal meliputi faktor admistratif, sosialisasi dan faktor politik. Faktor admistratif berkaitan dengan aspek adminstratif yang menyebabkan pemilih tidak bisa menggunakan hak pilihnya diantaranya tidak terdata sebagai pemilih, tidak mendapatkan kartu pemilih, dan tidak memiliki identitas kependudukan (KTP). Faktor sosialisasi yaitu penyebarluasan informasi mengenai pemilihan umum kepada masyarakat setiap kali pemilu.dan faktor politik adalah alasan atau penyebab yang timbul oleh aspek politik yang timbul seperti ketidak percayaan kepada partai, tak punya pilihan dari kandiddat yang tersedia atau tak percaya bahwa pileg atau pilkada akan membawa perubahan dan perbaikan.

Penelitian ini difokuskan pada masyarakat yang tidak menggunakan hak pilihnya (golput) sedangkan penelitian saya bukan hanya untuk mengetahui alasan orang tidak menggunakan hak suaranya tetapi secara umum mau menjelaskan apa yang menyebakan partisipasi tetapi juga mengetahui mengapa partisipasi masyarakat dalam pemilihan kepala daerah di Kota Denpasar itu berada dibawah standar nasional. Adapun yang menjadi rumusan masalah dalam penulisan ini, yaitu : "Bagaimana Partisipasi Politik Masyarakat dalam pemilihan umum Legislatif di Kota Denpasar Periode 2014-2019?’.

Sedangkan tujuan penulisan artikel ini bertujuan untuk mengetahui peran serta politik masyarakat dalam pemilu legislatif di Kota Denpasar Periode 2014-2019 dan diharapkan dapat memberi manfaat memberikan informasi yang bersifat ilmiah bagi pengembangan ilmu pengetahuan serta keberhasilan pelaksanaan melalui proses pembangunan politik yang demokrasi melalui pelaksana Pemilu Legislatif di Kota Denpasar dalam kaitannya dengan partisipasi politik masyarakat. 


\section{KAJIAN TEORI}

Sikap adalah bentuk dari pemahaman yang muncul tentang realitas yang ada, dengan menggunakan preferensi dan bangunan pengetahuan yang ada. Sedangkan partisipasi politik adalah keikutsertaan warga negara biasa dalam menentukan segala keputusan yang menyangkut atau mempengaruhi kehidupannya (Ramlan Surbakti, 2010:140). Sikap belum tentu adalah partisipasi, tapi partisipasi adalah sikap politik. Diam dalam artian tidak ikut dalam suatu kegiatan politik atau tidak berpartisipasi, merupakan suatu sikap politik. Sikap politik dan juga pilihan politik, diawali oleh terbentuknya persepsi. Persepsi ini terbentuk dari hasil interaksi antara stimulus politik dengan kesadaran kognitif atau alam pikiran seseorang (Adman Nursal, 2004:27). Hal ini nantinya akan mempengaruhi sikap, aspirasi, perilaku politik dan juga pilihan politik.

\section{Partisipasi Politik}

Adapun pengertian partisipasi politik menurut Michael Rush dan Philip Althoft partisipasi politik sebagai kegiatan warga Negara biasa dalam mempengaruhi proses pembuatan dan pelaksanaan kebijakan umum dan dalam ikut serta menentukan pemimpin pemerintahan. Segala kegiatan warga Negara yang mempengaruhi proses pembuatan serta pelaksanaan kebijakan umum termasuk dalam memilih pemimpin pemerintahan dapat digolongkan sebagai kegiatan partisipasi politik (Damsar, 2010:181).

Samuel P. Huntington dan Joan Nelson dalam bukunya yang berjudul pembangunan politik di Negara-negara berkembang memberi tafsiran yang lebih luas dengan memasukkan secara eksplisit tindakan illegal dan kekerasan. Menurut mereka, partisipasi politik adalah kegiatan warga Negara yang bertindak sebagai pribadi-pribadi yang dimaksud untuk mempengaruhi pembuatan keputusan oleh pemerintah, karena partisipasi bisa bersifat individual atau kolektif, terorganisir atau spontan, mantap atau sporadic, secara damai atau dengan kekerasan, legal atau illegal, efektif atau tidak efektif (dalam Miriam Budiharjo, 2008:368). 
Pemilu adalah arena kompetisi untuk mengisi jabatan-jabatan politik di pemerintahan yang didasarkan pada pilihan formal dari warga Negara yang memenuhi syarat. Pada zaman modern ini pemilu menempati posisi penting karena terkait dengan beberapa hal; Pertama, pemilu menempati posisi penting bagi keberlangsungan demokrasi perwakilan. Kedua, pemilu menjadi indikator negara demokrasi. Dhal mengatakan bahwa dua dari enam ciri lembagalembaga politik yang dibutuhkan oleh demokrasi skala besar adalah berkaitan dengan pemilu, yaitu para pejabat yang dipilih dan pemilu yang bebas adil dan berkala. Ketiga, pemilu penting dibicarakan juga terkait dengan implikasi-implikasi yang luas dari pemilu, pada fase tersebut Huntington menyebut pemilu sebagai alat serta tujuan dari demokratisasi. Pernyataan tersebut berangkat dari kenyataan tumbangnya penguasa-penguasa otoriter akibat dari pemilu yang mereka sponsori sendiri karena mencoba memperbaharui legitimasi melalui pemilu. (Ranadireksa, 2007).

Rakyat membuat kontrak sosial dengan para pemimpin melalui pemilu. Pada saat pemilu rakyat dapat memilih figur yang dapat dipercaya untuk mengisi jabatan legislatif dan eksekutif. Di dalam pemilu, rakyat yang telah memenuhi syarat untuk memilih, secara bebas, dan rahasia, menjatuhkan pilihannya pada figur yang dinilai sesuai dengan aspirasinya. Oleh karena itu, kekuasaan yang dimiliki oleh para pemimpin sekarang bukanlah muncul karena dirinya sendiri, melainkan titipan dari rakyat melalui pemilu. Intinya, pemilihan umum adalah suatu contoh partisipasi politik yaitu kegiatan warga negara biasa dalam mempengaruhi kebijakan pemerintah. Pada hakekatnya pemilihan umum merupakan cara dan sarana yang tersedia bagi rakyat unutk menentukan wakilwakilnya yang akan duduk dalam badan-badan perwakilan rakyat untuk menjalankan kedaulatan rakyat. Sangat bermaknanya pemilu bagi semua orang, maka pemilihan yang menjadi indikator demokratisnya suatu negara.

Berangkat dari batasan pengertian partisipasi politik dalam pemilihan umum tersebut. Pada akhirnya penelitian ini juga tidak bisa menafikan karakteristik sosial yang terjadi dalam objek penelitian, terkhusus Garut. Sebab pada akhirnya peneliti juga harus bisa mengiyakan ada faktor lain yang mempengaruhi partisipasi politik ini. Studi hasil penelitian Seymour Martin Lipset, dalam Political Man: the Social Bases of Politics (1960) dalam Miriam Budihardjo,2008) menegaskan dengan sangat terang bahwasanya karakteristik sosial berpengaruh terhadap partisipasi politik. Karakteristik sosial tersebut meliputi pendapatan, 
pendidikan, pekerjaan, ras, jenis kelamin, umur, tempat tinggal, situasi kondisi, status dan organisasi. Dengan demikian karakteristik sosial khas kegarutan, menjadi bumbu pelengkap dalam pembahasan penelitian ini.

\section{Pilihan Rasional}

Coleman3 memaknai teori pilihan rasional sebagai tindakan perseorangan mengarah kepada sesuatu tujuan dan memandang tujuan itu ditentukan oleh nilai atau pilihan. Ada dua unsur utama dalam teori Coleman (Miriam Budihardjo, 1998) yakni aktor dan sumber daya. Aktor adalah yang memilih tindakan yang dapat memaksimalkan kegunaan atau memuaskan keinginan dan kebutuhan mereka. Sedangkan sumber daya adalah sesuatu yang menarik perhatian dan yang dapat dikontrol oleh aktor. Buah karya pemikiran Downs (Marsh \& Stoker, 2010), pilihan rasional berkembang dalam arah yang bervariasi. Teori pilihan rasional mengambil preferensi, keyakinan, dan strategi feasible individu sebagai penyebab tindakan yang mereka lakukan. Varian mainstream dari pilihan rasional mengasumsikan bahwa individu mempunyai semua kapasitas rasional, waktu, dan keterikatan emosi yang penting untuk memilih arah tindakan baik, tak peduli betapa kompleksnya pilihan tersebut. Masalah paling sederhana secara konseptual dalam pembuatan keputusan parametrik dalam kepastian ketika setiap tindakan mempunyai hasil yang diketahui (sehingga tidak ada resiko atau ketidakpastian) dan hubungan antara aksi dan akibat tak dipengaruhi oleh tindakan individu lain. Individu diasumsikan mampu menilai hasil, maupun aksi.

Lebih lanjut Downs4 mengatakan, dalam konteks pemilihan umum orang memilih calon atau partai politik, apabila calon atau partai tersebut dipandang dapat membantu pemilih memenuhi kepentingan dasarnya yakni kehidupan ekonomi. Cukup dengan mempersepsikan keadaan ekonomi dirinya (egosentrik) di bawah sebuah pemerintahan (partai atau calon) tertentu sekarang ini dibanding sebelumnya (retrospektif), dan yang akan datang dibanding sekarang (retroospektif), dan yang akan datang dibanding sekarang (prospektif); dan evaluasi umum seorang pemilih atas keadaan ekonomi nasional (sosiotropik) di bawah pemerintahan sekarang dibanding tahun sebelumnya (retospektif), dan keadaan ekonomi nasional dibawah pemerintahan sekarang dibanding tahun-tahun yang akan datang (prospektif). 
Lembaga sosial telah berperan besar dalam meningkatkan partisipasi politik masyarakat Seperti yang diaungkapkan oleh Friedmen dan Hechter yang menjelaskan adanya kemampuan dari lembaga sosial untuk memberikan sanksi positif dan negatif kepada masyarakat sehingga mempengaruhi masyarakat untuk menentukan ikut berpartisipasi ataukah tidak. Dari penjelasan Friedmen dan Hecdter tersebut dalam permasalahan partisipasi politik lembaga sosial mampu memberikan dorongan kepada masyarakat untuk turut berpartisipasi dalam politik. Berdasarkan pengamatan peneliti, lembaga sosial yang turut berperan dalam meningkatkan partisipasi politik masyarakat antara lain adalah penyelenggara pemilu (KPU, PPK, PPS, dan KPPS), Partai Politik, Media Massa, dan Ormas.

\section{METODE PENELITIAN}

Penelitian tentang partisipasi politik pemilih Pemilu Legislatif menggunakan penelitian kualitatif dan kuantitatif. Prosedur penelitian kualitatif menurut Moleong (2008) menghasilkan data deskriptif berupa kata tertulis atau lisan dari orang yang menjadi obyek atau responden penelitian responden. Melalui pendekatan ini diharapkan dapat mengumpulkan realita di lapangan dengan mengumpulkan data secara langsung melalui wawancara, dokumentasi dan observasi. Menurut Whitney, penelitian deskriptif adalah pencarian fakta dengan interpretasi yang tepat dengan tujuan untuk membuat deskripsi, gambaran/lukisan, secara sistematis, faktual dan akurat mengenai fakta-fakta, sifat-sifat serta hubungan-hubungan antar fenomena yang diselidiki. Sementara penelitian kualitatif bertitik tolak dari paradigma fenomenologis yang objektivitasnya dibangun atas rumusan tentang situasi tertentu sebagaimana yang dihayati oleh individu atau kelompok sosial tertentu dan relevan dengan tujuan penelitian itu.

Tujuan penelitian kualitatif adalah bukan untuk selalu mencari sebab akibat sesuatu, tetapi lebih berupaya memahami situasi tertentu. Hasil yang diperoleh dalam penelitian deskriptif selanjutnya lebih ditekankan pada memberikan gambaran secara objektif tentang keadaan sebenarnya dari obyek yang diteliti. Penelitian ini adalah penelitian deskriptif dengan menggunakan data kualitatif. Penelitian kuantitatif menggunakan analisis statistik deskripstif terhadap data sekunder yang terkait karakteristik sosial ekonomi, dan kondisi pemilih dan 
partai politik pada Pemilu Legislatif 2014. Analisa dilakukan sejak data awal penelusuran dan dilakukan secara terusmenerus sampai menemukan data yang sesuai dengan batasan penelitian.

\section{PEMBAHASAN}

Partisipasi politik masyarakat merupakan bentuk perwujudan negara demokrasi, dimana masyarakat dilibatkan langsung dalam Pemilihan Umum. Dalam hal ini, warga negara berperan penting dalam menseleksi pejabat-pejabat negara yang nantinya akan mengatur pemerintahan maupun tindakan-tindakan yang akan mereka ambil nantinya (Suryadi, 2007).

Partisipasi politik adalah hasrat seorang individu untuk mempunyai peran dalam kehidupan politik melalui keterlibatan administratif untuk menggunakan hak bersuara, melibatkan dirinya diberbagai organisasi, mendiskusikan berbagai persoalan politik dengan pihak lain, ikut serta melakukan berbagai aksi dan gerakan, bergabung dengan partai-partai atau organisasi-organisasi independent, ikut serta dalam kampanye penyadaran, memberikan penyadaran, memberikan pelayanan terhadap lingkungan dengan kemampuanya sendiri (Arther Muhaling, 2014).

Partisipasi politik dapat bermanfaat untuk: (1) memberikan dukungan kepada penguasa dan pemerintah dalam bentuk pengiriman wakil atau pendukung, pembuatan pernyataan yang isinya memberikan dukungan terhadap pemerintah, dan pemilihan calon yang diusulkan oleh organisasi politik; (2) menunjukan kelemahan dan kekurangan pemerintah dengan harapan agar pemerintah meninjau kembali, memperbaiki, atau mengubah kelemahan tersebut; (3) partisipasi sebagai tantangan terhadap penguasa supaya terjadi perubahan struktural dalam pemerintahan dan dalam sistem politik (Syamsudin Haris, 2014).

Bahwa semua warga negara memiliki peluang dan kesempatan yang sama dalam mengevaluasi dan menentukan pemimpinnya, sehingga partisipasi politik, dalam hal ini keikutsertaan warga negara dalam Pemilu, menjadi penting. Pada sisi yang sama, pemahaman yang baik terhadap peran-peran strategis warga negara juga akan mendorong kualitas demokrasi (Liando, 2016). 
Manakala Pemilihan legislatif memang diakui secara global, sebagai sebuah arena untuk membentuk demokrasi perwakilan serta menggelar pergantian pemerintahan secara berkala (Rahmatunnisa, 2017). Tujuan utama pemilu legislatif adalah rakyat daerah bisa menentukan sendiri orang tertentu yang dianggap atau dinilai mampu membawa kebaikan bagi seluruh rakyat di daerah tersebut. Pemilihan Kepala Daerah secara langsung dinilai sebagai sarana dan cermin atas hak dasar kedaulatan rakyat dengan memberikan kewenangan yang utuh dalam melaksanakan serta menentukan pimpinan daerah untuk mewujudkan demokrasi tingkat lokal. Menurut teori demokrasi minimalis dari Schumpeterian, pemilu legislatif merupakan sebuah arena yang mewadahi kompetisi atau kontestasi antara aktor politik untuk meraih kekuasaan; partisipasi politik rakyat untuk menentukan pilihan; serta liberalisasi hak-hak sipil dan politik warga negara (Harahap, 2010) (Liando, 2016) (Mitchell, 2015).

Demokrasi juga menggariskan bahwa Pemilu Legislatif adalah kesempatan bagi partai oposisi dan rakyat untuk menjalankan mekanisme check and balances terhadap partai yang berkuasa atau ruling party (Asrinaldi, 2013). Meski banyak kalangan menilai konsepsi demokrasi seperti ini cenderung minimalis, namun praktek demokrasi yang minimalis tersebut telah membentuk sebuah sistem penentuan/ pengisian jabatan-jabatan publik di semua negara demokratis. Artinya bahwa pemilu legislatif telah terlembaga secara institusional dan menjadi mekanisme universal dalam sistem politik di negara-negara demokratis (Liando, 2016).

Dalam konteks pemilu legislatif, mekanisme pemilihan dikatakan demokratis apabila memenuhi beberapa parameter, yakni: adanya pemilihan kepala daerah yang jujur dan adil; rotasi kekuasaan yang damai; rekrutmen secara terbuka; dan akuntabilitas (Nopyandri, 2012). Merujuk pada pandangan tersebut, semakin jelas bahwa semangat demokrasi menuntut ruang partisipasi yang luas dan telah mengkonstruksi sistem demokrasi kita pada demokrasi langsung, dimana rakyat secara langsung berpartisipasi untuk menentukan pilihan politiknya tanpa diwakilkan. 
Berikut dalam penelitian ini karakteristik narasumber yang dikemukakan adalah jenis kelamin, umur, pekerjaan, dan pendidikan. Berikut karakteristik responden di uraikan sebagai berikut :

Tabel 1 Karakteristik Narasumber Berdasarkan genetik

\begin{tabular}{|l|l|c|}
\hline \multicolumn{1}{|c|}{ Jenis Kelamin } & F & Prosentase (\%) \\
\hline Laki - laki & 18 & 45 \\
\hline Perempuan & 22 & 55 \\
\hline Jumlah & 40 & 100 \\
\hline
\end{tabular}

Sumber : olahan data, 2015

Tabel 1 diatas menunjukan responden didominasi oleh perempuan yaitu 22 orang (55\%) dan laki-Iaki 18 orang ( $45 \%)$.

Tabel 2 Karakteristik Narasumber Berdasarkan usia

\begin{tabular}{|l|c|c|}
\hline \multicolumn{1}{|c|}{ Umur } & F & Prosentase $(\%)$ \\
\hline$<20$ tahun & 2 & 5 \\
\hline $21-30$ tahun & 7 & 17.5 \\
\hline $31-40$ tahun & 12 & 30 \\
\hline $41-49$ tahun & 13 & 32.5 \\
\hline 50 tahun keatas & 6 & 15 \\
\hline Jumlah & 40 & 100 \\
\hline
\end{tabular}

Sumber : olahan data, 2015

Tabel 2 menunjukan bahwa umur responden di dominasi oleh umur 41-49 tahun terdapat 13 orang (32,5\%) kemudian umur 31-40 tahun terdapat 12 orang (30\%), umur 71-30 tahun terdapat 7 orang $(17,5 \%) 50$ tahun keatas terdapat 6 orang $(15 \%)$ dan usia kurang dari 20 tahun terdapat 2 orang $(5 \%)$.

Tabel 3 Partisipasi Masyarakat dalam proses seleksi calon anggota Legislatif pada Pemilu Legislatif tahun 2014 di Kota Denpasar

\begin{tabular}{|c|l|c|c|}
\hline No & \multicolumn{1}{|c|}{$\begin{array}{c}\text { Partisipasi dalam proses } \\
\text { seleksi calon }\end{array}$} & F & $\begin{array}{c}\text { Prosentase } \\
(\mathbf{\%})\end{array}$ \\
\hline a & Sering/aktif & 12 & 30 \\
\hline b & Jarang/cukup aktif & 22 & 55 \\
\hline c & Tidak pernah & 6 & 15 \\
\hline & Jumlah & 40 & 100 \\
\hline
\end{tabular}

Sumber : olahan data, 2015 
Dari tabel 3 diatas terlihat bahwa dari 40 orang responden masyarakat yang diwawancarai: 55\% menyatakan jarang berpartisipasi dalam proses seleksi calon anggota Legislatif pada Pemilu legislatif tahun 2014 di Kota Denpasar. 30\% menyatakan sering berpartisipasi dalam proses seleksi calon anggota Legislatif pada Pemilu Legislatif tahun 2014 di Kota Denpasar dan 15\% menyatakan tidak pernah ikut berpartisipasi dalam proses seleksi calon anggota Legislatif pada Pemilu Legislatif tahun 2014 di Kota Denpasar.

Jadi kesimpulannya bahwa partisipasi masyarakat dalam proses seleksi calon anggota Legislatifadalah kurang baik karena masyarakat jarang berpartisipasi dalam proses seleksi ini.

\section{Tabel 4 Partisipasi Masyarakat dalam memberikan suara pada saat pemungutan suara pada Pemilu Legislatif Tahun 2014 di Kota Denpasar}

\begin{tabular}{|l|l|c|c|}
\hline No & Partisipasi dalam memberikan suara & F & Prosentase ( \% ) \\
\hline a & Ikut memilih & 16 & 40 \\
\hline b & Tidak ikut memilih & 24 & 60 \\
\hline & Jumlah & $\mathbf{4 0}$ & $\mathbf{1 0 0}$ \\
\hline
\end{tabular}

Sumber : olahan data, 2015

Dari tabel diatas terlihat bahwa dari 40 orang responden masyarakat yang diwawancarai : (60\%) menyatakan tidak ikut berpartisipasi dalam memberikan suara pada Pemilu Legislatif tahun 2014 di Kota Denpasar (40\%), menyatakan ikut berpartisipasi dalam memberikan suara pada Pemilu Legislatif tahun 2014 di Kota Denpasar. Helion didukung dengan pandangan yang diberikan seorang ibu berinisial AY berusia 46 tahun yang mengatakan bahwa "buat apa memilih jika nantinya Anggota Dewan tidak dapat bekerja dengan baik untuk menyalurkan aspirasi masyarakat. Suara yang saya berikan nantinya akan menjadi sia-sia. Anggota Dewan hanya mengubar janji-janji saja saat pemilihan akan tetapi setelah meendapatkan kursi di DPRD lupa akan janjinya untuk mensejahterakan masyarakat. Dapat dilihat Anggota Dewan Periode yang lalu belum bisa merealisasikan apa yang mereka janjikan kepada masyarakat. Jadi lebih baik saya tidak memilih (golput)". 
Maka dapat disimpulkan bahwa partisipasi masyarakat dalam pemilihan umum Legislatif tahun 2014 di Kota Denpasar adalah tidak baik karena banyak masyarakat yang tidak memilih (golput).

Table 5 Latar belakang tidak ikut berpartisipasi dalam memberikan suara Pemilu Legislatif tahun 2014 di Kota Denpasar.

\begin{tabular}{|l|l|c|c|}
\hline No & \multicolumn{1}{|c|}{$\begin{array}{c}\text { Partisipasi dalam proses } \\
\text { seleksi calon }\end{array}$} & F & $\begin{array}{c}\text { Prosentase } \\
(\%)\end{array}$ \\
\hline a & Terlalu banyak partai \% caleg & 25 & 62.5 \\
\hline b & Cara memilih yang rumit & 5 & 12.5 \\
\hline c & Kurangnya sosialisasi & 10 & 25 \\
\hline & Jumlah & 40 & 100 \\
\hline
\end{tabular}

Sumber : Data Olahan, 2015

Dari tabel diatas terlihat dari 40 orang responden masyarakat yang diwawancarai: 62,5\% menyatakan tidak memberikan suara dalam Pemilihan Umum Legislatif tahun tahun 2014 di Kota Denpasar karena terlalu banyak partai dan caleg, 25\% menyatakan tidak memberikan suara dalam Pemilihan Umum Legislatif tahun 2014 karena kurangnya sosialisasi. dan $12,5 \%$ menyatakan tidak memberikan suara karena cara memilih yang rumit. Pendapat ini didukung oleh seorang bapak berinisial VL umur 53 tahun yang mengatakan dalam Pemilu Legislatif tahun 2014 ia tidak memberikan suaranya karena terlalu banyak partai dan jugaCalon Legislatif dari setiap partai tersebut sehingga saya merasa bingung untuk memilih Calon Anggota Legislatif mana yang harus dipilih.

Tabel 6 Penyaluran undangan dalam Pemilu Legislatif

Tahun 2014 di Kota Denpasar

\begin{tabular}{|l|l|c|c|}
\hline No & \multicolumn{1}{|c|}{ Penyaluran Undangan } & F & $\begin{array}{c}\text { Prosentase } \\
(\%)\end{array}$ \\
\hline a & Mendapat undangan & 40 & 100 \\
\hline b & Tidak mendapat undangan & 0 & 0.00 \\
\hline & Jumlah & 40 & 100 \\
\hline
\end{tabular}

Sumber : olahan data, 2015 
Dari tabel diatas terlihat dari 40 orang responden masyarakat yang diwawancarai 100\% menyatakan bahwa mendapatkan undangan untuk memilih pada Pemilu Legislatif tahun 2014 di Kota Denpasar.

\section{Tabel 7 Partisipasi masyarakat dalam Kampanye pemilu Legislatif}

Tahun 2014 di Kota Denpasar

\begin{tabular}{|l|l|c|c|}
\hline No & Partisipasi dalam kampanye & F & Prosentase (\% ) \\
\hline a & Sering & 4 & 10 \\
\hline b & Jarang & 10 & 25 \\
\hline c & Tidak pernah & 26 & 65 \\
\hline & Jumlah & 40 & 100 \\
\hline
\end{tabular}

Sumber : olahan data, 2015

Dari tabel diatas terlihat bahwa dari 40 orang responden masyarakat yang diwawancarai: 65\% menyatakan tidak pemah berperanserta dalam kampanye pada Pemilu Legislatif tahun tahun 2014 di Kota Denpasar menyatakan jarang berpartisipasi dalam kampanye pada Pemilu Legislatif tahun 2014 di Kota Denpasar dan 10\% menyatakan sering berpartisipasi dalam kampanye pada Pemilihan Umum Legislatif tahun tahun 2014 di Kota Denpasar. Hal ini ditunjang oleh pendapat yang disampaikan oleh seorang masyarakat yang berinisial W umur 45 tahun yang mengatakan lebih baik saya tinggal diruman daripada ikut berkampanye, karena sering terjadi kekacauan dalam kampanye tersebut sehingga saya merasa takut untuk mengambil konsekuensinya jika ikut berpartisipasi dalam kampanye.

Jadi dapat disimpulkan bahwa partisipasi masyarakat dalam kampanye pada Pemilu Legislatif tahun 2014 di Kota Denpasar adalah kurang baik karena banyak masyarakat yang tidak pemah ikut berkampanye. 
Tabel 8 Partisipasi masyarakat dalam mengawasi perhitungan suara pada Pemilu Legislatif Tahun 2014 di Kota Denpasar

\begin{tabular}{|l|l|c|c|}
\hline No & \multicolumn{1}{|c|}{$\begin{array}{c}\text { Partisipasi dalam } \\
\text { mengawasi perhitungan } \\
\text { suara }\end{array}$} & F & $\begin{array}{c}\text { Prosentase } \\
\mathbf{( \% ) ~}\end{array}$ \\
\hline a & Aktif ikut mengawasi & 4 & 10 \\
\hline b & Cukup aktif ikut mengawasi & 11 & 27,5 \\
\hline c & Kurang aktif mengawasi & 25 & 62.5 \\
\hline & Jumlah & 40 & 100 \\
\hline
\end{tabular}

Sumber : olahan data, 2015

Dari tabel diatas terlihat bahwa dari 40 orang respon Partisipasi masyarakat dalam mengawasi perhitungan suara pada Pemilu Legislatif tahun 2014 menyatakan cukup aktif ikut mengawasi penghitungan suara pada Pemilu Legislatif tahun 2014 dan 10\% menyatakan aktif ikut mengawasi proses penghitungan suara pada Pemilu Legislatif tahun tahun 2014 di Kota Denpasar. Dapat dilihat masyarakat kurang aktif mengawasi proses perhitungan suara pada Pemilihan Umum Legislatif tahun 2014 jadi dapat disimpulkan partisipasi masyarakat dalam perhitungan suara adalah cukup baik.

Tabel 9 Peran masyarakat dalam mengedepankan mekanisme demokrasi pada pemilu Legislatif tahun 2014 di Kota Denpasar

\begin{tabular}{|l|l|c|c|}
\hline No & \multicolumn{1}{|c|}{ Peran masyarakat } & F & $\begin{array}{c}\text { Prosentase } \\
\mathbf{( \% ) ~}\end{array}$ \\
\hline a & Selalu & 1 & 2.5 \\
\hline b & Sering & 13 & 32.5 \\
\hline c & Kadang/jarang & 16 & 65 \\
\hline & Jumlah & 40 & 100 \\
\hline
\end{tabular}

Sumber : olahan data, 2015

Dari tabel diatas terlihat bahwa dari 40 orang responden masyarakat yang diwawancarai $65 \%$ menyatakan kadang berpartisipasi dalam mengedepankan proses demokrasi pada Pemilu Legislatif tahun 2014 di Kota Denpasar menyatakan jarang berpartisipasi dalam mengedepankan mekanisme demokrasi pada Pemilu Legislatif tahun 
2014 di Kota Denpasar dan 2,5\% menyatakan sering berpartisipasi dalam mengedepankan mekanisme demokrasi pada Pemilu Legislatif tahun 2014 di Kota Denpasar.

Jadi dapat disimpulkan bahwa partisipasi masvarakat dalam mengedepankan mekanisme demokrasi pada Pemilu Legislatif tahun 2014 di Kota Denpasar adalah kurang baik.

\section{Tabel 10 Peran pemerintah daerah dalam mensosialisasikan}

Pemilu Legislatif Tahun 2014

\begin{tabular}{|l|l|c|c|}
\hline No & \multicolumn{1}{|c|}{ Mekanisme Pemilu } & F & $\begin{array}{c}\text { Prosentase } \\
(\mathbf{\%})\end{array}$ \\
\hline a & Sangat baik & 0 & 0.0 \\
\hline b & Baik & 19 & 47.5 \\
\hline c & Cukup baik & 21 & 52.5 \\
\hline d & Tidak baik & 0 & 0.0 \\
\hline & Jumlah & 40 & 100 \\
\hline
\end{tabular}

Sumber : Data Olahan, 2015

Dari tabel di atas terlihat bahwa dari 40 orang responden masyarakat yang diwawancarai : 52.5\% menyatakan bahwa peran Pemerintah daerah dalam mensosialisasikan pemilihan Umum Legislatif adalah cukup baik dan 47,5 \% menyatakan bahwa peran Pemerintah daerah dalam mensosialisasikan Pemilihan Umum Legislatif adalah baik. Hal itu didukung dengan pendapat yang disampaikan oleh seorang ibu rumah tangga yang berinisial WR umur 47 tahun yang mengatakan bahwa sosialisasi yang diberikan oleh daerah kepada masyarakat masih sangat kurang, dimana sosialisasi hanya disampaikan dalam pertemuan RT (Rukun Tetangga) saja tidak mengundang masyarakat secara keseluruhan untuk memberikan sosialisasi. 
Jadi dapat disimpulkan bahwa peran pemerintah daerah dalam mensosialisasikan Pemilihan Umum Legislatif tahun 2014 di Kota Denpasar.

Tabel 11 Pelaksanaan tugas oleh KPU dalam Pemilu Legislatif

Tahun 2014 di Kota Denpasar.

\begin{tabular}{|l|l|c|c|}
\hline No & \multicolumn{1}{|c|}{$\begin{array}{c}\text { Pelaksanaan Tugas } \\
\text { Oleh KPU }\end{array}$} & F & $\begin{array}{c}\text { Prosentase } \\
(\mathbf{\%})\end{array}$ \\
\hline a & Sangat baik & 0 & 0.0 \\
\hline b & Baik & 22 & 55 \\
\hline c & Cukup baik & 18 & 45 \\
\hline d & Tidak baik & 0 & 0.0 \\
\hline & Jumlah & 40 & 100 \\
\hline
\end{tabular}

Sumber : Data Olahan, 2015

Dari tabel diatas dapat dilihat dari 40 orang responden masyarakat yang diwawancarai : 55\% menyatakan bahwa KPU sudah menjalankan tugasnya dengan baik dalam Pemilihan Umum Legislatif tahun 2014 di Kota Denpasar dan 45\% menyatakan bahwa KPU menjalankan tugasnya dengan cukup baik.

Jadi dapat disimpulkan bahwa KPU sudah dapat menjalankan tugasnya dengan baik.

Tabel 12 Pelaksanaan Pemilu Legislatif disesuaikan pada

peraturan perundang- undangan.

\begin{tabular}{|l|l|c|c|}
\hline No & \multicolumn{1}{|c|}{$\begin{array}{c}\text { Pelaksanaan Tugas } \\
\text { Oleh KPU }\end{array}$} & F & $\begin{array}{c}\text { Prosentase } \\
(\mathbf{\%})\end{array}$ \\
\hline a & Sesuai & 24 & 60 \\
\hline b & Tidak sesuai & 16 & 40 \\
\hline & Jumlah & 40 & 100 \\
\hline
\end{tabular}

Sumber : olahan data, 2015

Dilihat dari tabel di atas dari 40 orang responden masyarakat yang diwawancarai 60\% menyatakan bahwa pelaksanaan Pemilihan Umum sesuai dengan Peraturan perundang-undangan dan $40 \%$ menyatakan bahwa pelaksanaan Pemilihan Umum Legislatif tidak sesuai dengan peraturan perundang-undangan. Ditunjang pendapat dari 
seorang tokoh agama GKS yang mengatakan pemilihan umum legislatif sudah sesuai dengan peraturan perundang-undangan karena dapat berjalan dengan baik. Jadi pemilihan umum Legislatif berjalan sesuai dengan peraturan perundang-undangan.

\section{KESIMPULAN}

Berdasarkan dari hasil penelitian, wawancara dan pengolahan data maka dapat disimpulkan bahwa, respon masyarakat di Kota Denpasar dalam mengikuti pemilu legislatif pada tahun 2014 dapat dismpulkan bahwa antusias dari mereka tinggi dalam partisipasi politik. Akan tetapi partisipasi mereka tinggi karena disebabkan adanya faktor mobilisasi yang dilakukan oleh calon legislatif membuat masyarakat ikut berpartisipasi dan membuat tingkat partisipasi di Denpasar menjadi tinggi. Kemudian terjadinya relasi aktor-aktor politik yang memiliki jabatan di pemerintahan baik tingkat kabupaten maupun provinsi. Dan yang terakhir adanya punishment atau reward.

Pada dasarnya masyarakat di Kota Denpasar telah menjalankan nilai-nilai dari partisipasi politik. Dimana ikut aktif dalam kegiatan pemilu legislarif. Ikut aktif dalam kegiatan memilih dan dipilih tapi dalam pelaksanaannya masih kurang tepat karena masih adanya kegiatan mobilisasi politik. Oleh karena itu partisipasi politik yang dilakukan masyarakat di Kota Denpasar perlu diperbaiki agar pelaksanaannya sesuai dengan nilai-nilai partisipasi politik yang baik dan benar.

\section{DAFTAR PUSTAKA}

Arther Muhaling, (2014). Partisipasi Politik Masyarakat Dalam Pemilukada di Kecamatan Siau Barat Selatan Kabupaten Sitaro. Jurnal Politico, 3(2). https://ejournal.unsrat.ac.id/index.php/politico/article/view/7100

Asrinaldi, A. (2013). Koalisi Model Parlementer dan Dampaknya pada Penguatan Kelembagaan Sistem Presidensial di Indonesia. Jurnal Penelitian Politik, 10(2).

Bismar Arianto. (2011). Analisis Penyebab Masyarakat Tidak Memilih Dalam Pemilu. Jurnal Ilmu Politik dan Ilmu Pemerintahan, 1(1). https://fisip.umrah.ac.id/wp- 
content/uploads/2012/03/JURNAL-ILMU-PEMERINTAHAN-BARU-KOREKSIlast_57_66.pdf.

Budiardjo, Miriam. (1998). Demokrasi Di Indonesia Demokrasi Parlementer dan Demokrasi Pancasila. Jakarta: PT. Gramedia Pustaka Utama.

Budiardjo, Miriam. (2008). Dasar-Dasar Ilmu Politik Edisi Revisi Keempat. Jakarta; PT Gramedia Pustaka Utama.

Damsar. (2010). Pengantar Sosiologi Politik. Jakarta : Kencana Prenada Media Group.

Harahap, H. I. (2010). Robert A. Dahl dan Studi tentang Fenomena Demokrasi di India. Jurnal POLITEIA, 2(1).

Liando, D. M. (2016). PEMILU DAN PARTISIPASI POLITIK MASYARAKAT ( Studi Pada Pemilihan Anggota Legislatif Dan Pemilihan Presiden Dan Calon Wakil Presiden Di Kabupaten Minahasa Tahun 2014 ). Jurnal LPPM Bidang EkoSosBudKum, 3(2), 14-28. https://ejournal.unsrat.ac.id/index.php/lppmekososbudkum/article/viewFile/17190/16738

Mitchell, B. (2015). Participatory Partnerships: Engaging and Empowering to Enhance Environmental Management and Qualityof Life. Social Indicators Research, 71, 123144.

Moelong, Lexy J. (2008). Metodologi Penelitian Kualitatif (edisi revisi, cetakan xxv). Bnadung: PT Remaja Rosdakarya. Liberty, Yogyakarta.

Muhaling, Arther. (2014). "Partisipasi Politik Masyarakat Dalam Pemilukada di Kecamatan Siau Barat Selatan Kabupaten Sitaro". (Skripsi) Jurusan Ilmu Pemerintahan FISIP UNSRAT Manado. Diakses dari http://eprints.undip.ac.id/48739/2/Bab__.pdf 28 November 2016, pukul 14:23 WITA.

Nopyandri. (2012). Pemilihan Kepala Daerah yang Demokratis dalam Perspektif UUD 1945. Jurnal Ilmu Hukum, 2(2).

Rahmatunnisa, M. (2017). Permasalahan Anggaran Pengawasan dalam Pemilihan Kepala Daerah Serentak Tahun 2015. Jurnal Bawaslu, 3(1), 79-44. 
Ranadireksa, H. (2007) . Arsitektur Konstitusi Demokratik, Bandung : Fokusmedia, 173-174.

Subakti, Ramlan. (2010). Memahami Ilmu Politik. Cetakan Ketujuh. Jakarta; PT Grasindo 